\title{
Using Turnitin to help students understand plagiarism
}

\author{
Angela Unger Waigand \\ University of Calgary in Qatar
}

\begin{abstract}
The use of plagiarism detection software such as Turnitin or SafeAssign has become common in higher education. While frequently used to catch plagiarism, some institutions have used it as a learning tool to help students better understand plagiarism and the conventions of academic writing. In an international branch campus in the Middle East, a survey was given to undergraduate students, primarily second language students, on the use of Turnitin to help with their writing. Most participants found that the software helped them improve their paraphrasing skills, understand the use of citations, avoid plagiarism and, to a lesser extent, improve their language skills.

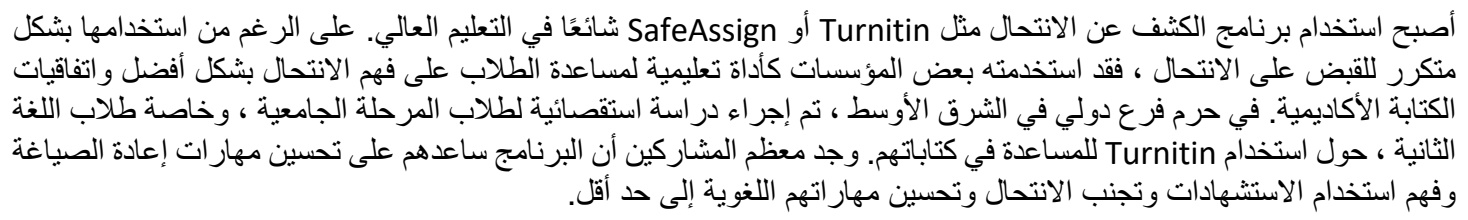

\section{Introduction}

Although plagiarism is ubiquitous in students' academic writing, not all plagiarism is committed with the intent to deceive. In fact, plagiarism is frequently unintentional. A significant body of research has suggested that a low-level of English language proficiency can lead to plagiarism (Currie, 1998; Keck, 2006; Shi, 2004; Shi, 2012; Walker, 2010). Given that most students at our institution are not English as a first language students and are often inexperienced with writing academic papers, the university began to give students within the foundation program access to Turnitin, plagiarism detection software, with the intent of using it as a formative assessment and assisting them with developing their academic writing. Within the foundation program, Turnitin was used as a self-directed learning tool, which opened a dialogue about plagiarism and appeared to help students develop their paraphrasing and summarizing skills as well as gain independence with integrating source material into their own writing.

After its successful use in the foundation program, the researcher's institution provided all students with access to Turnitin, administered through the university's writing centre. Although instructors did not have access to Turnitin, they could require that students submit a Turnitin report with their assignments. Students were provided with extensive training options for understanding and using the tool, and writing centre staff provided personal assistance for students to help them understand their reports and address their writing and citation errors. Similarly, instructors were provided with training on how to assist students with understanding their reports and how to use that information to help them revise.

In order to determine the effectiveness of this institutional initiative, students were given a survey to complete. The overarching research question guiding this study was: What are students' perceptions on the use of Turnitin? The aim of this paper is to describe the results of the study and explain the pedagogical implications that the results suggest. 


\section{Context}

This study was conducted at a small branch international campus located in the Middle East. All students in the university are studying for a Bachelor of Nursing or Master of Nursing degree. A vast majority of these students are English as a foreign language (EFL) students, and all students take the IELTS or TOEFL exam in application for university acceptance. Those with the required minimum score enter nursing directly, while the others take English for Academic Purposes (EAP) courses in the foundation program prior to matriculation. Students who pass all levels of EAP matriculate without having to retake an IELTS or TOEFL exam.

\section{Key concepts}

Many researchers distinguish between plagiarism committed with the intent to deceive versus plagiarism that is unintentional. In fact, some research suggests that many students have no intent to deceive when they plagiarize (Chandrosoma, Thompson, \& Pennycook, 2004; Currie, 1998; Pecorari, 2003). Students may be ill-prepared for the rigors and complexities of academic reading (MacMillan \& Rosenblatt, 2015) and lack the ability to synthesize material (Carlozzi, 2018; Rosenblatt, 2010), factors which may complicate the writing process. A lack of knowledge of academic writing conventions, including students' confusion over how to paraphrase, synthesize source work, and cite sources may affect students' likelihood to plagiarize (Abasi \& Graves, 2008; Gullifer \& Tyson, 2010; Shi, 2012). Other factors can include differences in cultural attitudes (Chandrasoma, Thompson, \& Pennycook., 2004; Pennycook, 1996; Shi, 2004) and language proficiency (Currie, 1998; Johns \& Mayes, 1990; Keck, 2006; Shi, 2004; Shi, 2012; Walker, 2010). It has been suggested that plagiarism may be a "necessary phase" of academic development for both L1 and L2 writers but even more so for L2 writers (Chandrosoma et al., 2004; Elander, Pittam, Lusher, Fox, \& Payne, 2010; Flowerdew \& Li, 2007; Howard, 1995; Hyland, 2001). In earlier work, Howard (1992) coined the term patchwriting, which consists of

copying from a source text and then deleting some words, altering grammatical structures, or plugging in one-for-one synonym substitutions. (p. 233)

Students with lower proficiency levels may be more prone to patchwriting (Flowerdew \& Li, 2007; Pecorari, 2003) but over time they may reduce their reliance on original sources and begin to adapt to the discourse of their new academic communities with its own guidelines, rhetoric, and vocabulary.

\section{Plagiarism education}

As educators, it is incumbent upon us not only to determine whether or not an academic transgression has taken place but also to educate learners in the accepted practices of academic writing. Learners need and, in many cases, want plagiarism education to help them acculturate to academia. Various strategies could be incorporated into such an approach for plagiarism education. Elander et al. (2010) have suggested that a holistic approach involves three categories: plagiarism software detection, honour codes, and instruction that helps students improve their writing skills. The writer's institution has incorporated all of these practices into their strategy for academic integrity, but the focus of this paper is on the first: the use of plagiarism detection software, specifically the use of Turnitin.

After a paper has been submitted, Turnitin compares the work with web pages, a wide variety of journal articles, conference proceedings, and books as well as students' archived papers (Turnitin, n.d.). The software identifies passages in students' papers that match passages from these other sources. Turnitin then generates what it terms an Originality Report, which highlights possible plagiarism on students' papers and provides a link to its match. Many institutions use Turnitin or other similar software to identify plagiarism. While some have taken a punitive approach, others have used the tool to help students to understand the practices of academic writing by increasing students' awareness of citation practices and paraphrasing strategies. The rationale for such an approach is that 
such software visually identifies sections of students' papers that match the original source. This visual representation helps students understand what plagiarism looks like and how to avoid it. Such a method puts the responsibility on students and helps familiarize them with academic expectations.

Research has been conducted on the use of plagiarism detection software and its effectiveness. Research on students' perceptions of its use have yielded primarily positive results (Betts, Bostock, Elder, \& Trueman, 2012; Bikowski, 2012; Ledwith \& Risque, 2008; Savage, 2004). The use of plagiarism detection appeared to deter students from plagiarising (Dahl, 2007; Stapleton, 2012). In a survey of graduate students conducted by Dahl (2007), results suggested that students appreciated being able to ask for clarification regarding plagiarism. Bikowski (2012) surveyed 141 non-native English speakers and found that students believe tools such as Turnitin are useful in helping them understand plagiarism. In Bailey and Challen's study (2015), students stated that Turnitin aided them in learning about appropriate source use.

Not all research has yielded such positive results. In an analysis of students' papers, Rolfe (2011) found no improvement in citation or referencing after having used Turnitin. Despite this, she did find that using Turnitin seemed to initiate a reflective process, causing students to think more about their writing and engage in the writing process. Biggam and McCann (2010) found that incorrect referencing and minor plagiarism persisted even after using plagiarism detection software. Nevertheless, they did conclude that similarity scores decreased over time although they cautioned that it may have been a result of learning from mistakes or learning how to "get around" the program. In one study in the U.K., Thompsett and Ahluwalia (2010) found that students did not perceive Turnitin as an effective deterrent, concluding that the results may be due to a lack of training in how to use it. In their study with EFL students in a university in Indonesia, Nova and Utami (2018) reported that the perceived inaccuracy of the Turnitin reports made the students feel unfavourably towards the tool.

Stapleton (2012) cautioned that there is a need for instructors and students to understand that percentage matches are "rough indicators, rather than definitive conclusions about the extent of plagiarism within text" (p.132) and that students need clear guidelines regarding plagiarism and how to avoid it. Similarly, Betts et al. (2012) noted that students need help to interpret their reports, specifically understanding when a false match has been identified.

\section{Methods}

The university implemented a university-wide initiative intended to help educate students on plagiarism and assist them with their academic writing. Prior to its introduction to the rest of the university, the EAP program had been successfully using Turnitin with students in the program for five semesters. The primary purpose for use in EAP classes was to identify sources in students' academic writing that had not been quoted or sentences that had been poorly paraphrased.

The initiative throughout the institution began after several faculty members had commented on students' patchwriting. In order to remove the perception that Turnitin was being used to 'catch' students, instructors did not have access to the program. Instead, administration of the initiative was conducted through the university writing centre. Instructors could choose to require that students submit Turnitin reports. Students were responsible for uploading their own assignments and could view their own reports. If students found problems with their citation and/or paraphrasing skills, they had an opportunity to revise and resubmit prior to submitting a final report to their instructor.

In order to facilitate the process, writing centre staff conducted class visits to teach students how to use the technology and how to understand their reports. The visits were initiated by instructors. Most instructors who used Turnitin in class requested visits; however, others did not. Additional workshops were offered to students outside of class time. Students were also able to make appointments to discuss their reports with writing centre staff and to have additional help with revision. Faculty members also received training to help them understand what Turnitin does and does not do and how 
to assist students with understanding their reports. An extensive training manual was also developed for faculty use.

A paper survey (see Appendix) was given to students asking for their perceptions of plagiarism and Turnitin. The survey was offered to all students currently enrolled in the Bachelor of Nursing program. Participation was requested in person through class visits as well as through email. The survey measured the perceptions and opinions of students on their use of Turnitin. The survey included three 4-point Likert scale questions on students' views of plagiarism, which all students were asked to complete. A yes/no question asked if students had used Turnitin before. Students who had not used it were asked an open-ended question about why they had not used it but did not complete the remaining questions on the survey. Two additional yes/no questions asked about whether the tool was required by instructors and whether students had used Turnitin by choice. Eleven 4-point Likert scale questions surveyed students' views on the use of Turnitin, both on its effect on their writing and on the technological aspect of it. Two yes/no questions elicited whether or not students had sought help with Turnitin and had received formal training. Two follow-up 4-point Likert scale questions surveyed students on the effectiveness of the help and training. Results were tallied and scores were calculated. The survey also included three open-ended questions asking students' opinions and suggestions. Results of these open-ended questions were coded and tallied.

Prior to beginning data collection, ethical approval for this research was granted by the University of Calgary Research Ethics Board.

\section{Participants}

Surveys were distributed to 382 students, with 139 students completing the survey, for a response rate of $36.4 \%$. A majority of the students, $73.4 \%$, had studied in EAP prior to matriculation, while $26.6 \%$ of them were direct-entry students. Eighty-nine, or $64 \%$, of respondents spoke Arabic as their first language, and 31 , or $22 \%$, spoke Malayalam as their first language. Of the remaining, the following language groups were represented: Tagalog (5), Farsi (4), Bengali (2), Somali (2), Pashto (2), Kiswahili (1), Balochi (1), Hindi (1), and Afrikaans (1). In terms of language and ethnicity, respondents were representative of the institution's student population. All students responded to the general questions on students' views of plagiarism. Of these students, 116 (83.5\%) had used Turnitin. These students completed the remaining questions on the survey, while the others did not.

\section{Findings}

\section{Views on plagiarism}

All 139 students completed the section on views on plagiarism. The results suggest that there is general concern among the students about plagiarism, with high responses strongly agreeing to each question (Table 1). A comparison between students who had studied in EAP and those who entered nursing directly shows a difference between the two groups for one question, in particular. Former EAP students strongly agreed (49\%) that they worried about plagiarizing compared to the direct-entry students (24\%) (independent samples $t$ test, $p<0.05$ ).

Table 1: Views on plagiarism

\begin{tabular}{lllllc}
\hline Survey question & $\begin{array}{l}\text { Strongly } \\
\text { agree }\end{array}$ & Agree & Disagree & $\begin{array}{l}\text { Strongly } \\
\text { disagree }\end{array}$ & $\begin{array}{l}\text { No } \\
\text { response }\end{array}$ \\
\hline Plagiarism is a problem at UCQ. & $46 \%$ & $30.2 \%$ & $16.5 \%$ & $2.9 \%$ & $4.3 \%$ \\
$\begin{array}{l}\text { Instructors are too strict about plagiarism. } \\
\text { I worry about accidental plagiarism in my }\end{array}$ & $62.8 \%$ & $31.7 \%$ & $4.3 \%$ & $0.7 \%$ & $0 \%$ \\
\begin{tabular}{l} 
writing. \\
\hline
\end{tabular}
\end{tabular}


Only the 116 students who had used Turnitin at least once completed the remaining questions. Of these, $28.4 \%$ had used Turnitin only once, $37.1 \%$ had used it two or three times, $32.6 \%$ had used it four or more times, and $1.7 \%$ did not respond. $85.3 \%$ were required to use Turnitin for at least one of their classes, while $21.9 \%$ were not. A total of $34.5 \%$ of the students used Turnitin for their assignments even if their instructors did not require it.

\section{Helpfulness of Turnitin}

Students generally found that Turnitin was useful and made them more aware of plagiarism (Table 2). Some also found that it helped them paraphrase and cite their work better. To a lesser extent, students found that it helped their language skills. A comparison between students who had been in EAP and those who had not was also conducted. Results of the analysis for most questions were similar, but there were some notable differences. The former EAP students were more likely to strongly agree (54\%) that they understood the benefits of Turnitin than the direct-entry students (24\%). They were also more likely to strongly agree that it helped them paraphrase better, with $36 \%$ of EAP students compared to $20 \%$ direct-entry students strongly agreeing.

Table 2 : Helpfulness of Turnitin

\begin{tabular}{llllll}
\hline Survey question & $\begin{array}{l}\text { Strongly } \\
\text { agree }\end{array}$ & Agree & Disagree & $\begin{array}{c}\text { Strongly } \\
\text { disagree }\end{array}$ & $\begin{array}{c}\text { No } \\
\text { response }\end{array}$ \\
\hline I understand the benefits of using Turnitin. & $47.7 \%$ & $49.2 \%$ & $1.7 \%$ & $.9 \%$ & $.9 \%$ \\
Using Turnitin made me more aware of plagiarism. & $44.8 \%$ & $52.6 \%$ & $.9 \%$ & $0 \%$ & $1.7 \%$ \\
Using Turnitin helped me to avoid plagiarism. & $44.8 \%$ & $50 \%$ & $4.3 \%$ & $0 \%$ & $.9 \%$ \\
I paraphrased better because of Turnitin. & $32.6 \%$ & $53.4 \%$ & $12.1 \%$ & $0 \%$ & $1.8 \%$ \\
$\begin{array}{l}\text { Using Turnitin helped me understand problems with } \\
\text { citations. }\end{array}$ & $34.5 \%$ & $46.6 \%$ & $15.5 \%$ & $1.7 \%$ & $1.7 \%$ \\
It is difficult to fix my writing based on the Turnitin & $12.1 \%$ & $36.2 \%$ & $42.2 \%$ & $6 \%$ & $3.4 \%$ \\
report. & & & & & \\
Using Turnitin had no effect on my writing. & $7.8 \%$ & $21.6 \%$ & $56.9 \%$ & $11.2 \%$ & $2.6 \%$ \\
My language skills improved because of Turnitin. & $14.7 \%$ & $47.4 \%$ & $35.3 \%$ & $.9 \%$ & $.9 \%$ \\
\hline
\end{tabular}

\section{Ease of use of Turnitin}

Most students (82.7\%) strongly agreed or agreed that Turnitin was easy to use and understand (Table 3). However, the results were mixed regarding how confusing and time-consuming the tool is. A comparison between former EAP students and direct-entry students again indicated one difference; EAP students were more likely to disagree or strongly disagree that reports are confusing $(59 \%)$, compared to $40 \%$ of direct-entry students.

Table 3: Ease of use of Turnitin

\begin{tabular}{llllll}
\hline Survey question & $\begin{array}{l}\text { Strongly } \\
\text { agree }\end{array}$ & Agree & Disagree & $\begin{array}{l}\text { Strongly } \\
\text { disagree }\end{array}$ & $\begin{array}{l}\text { No } \\
\text { response }\end{array}$ \\
\hline Turnitin was easy to use and understand. & $26.7 \%$ & $56 \%$ & $13.8 \%$ & $0 \%$ & $2.6 \%$ \\
Turnitin reports are confusing. & $4.3 \%$ & $31.9 \%$ & $55.2 \%$ & $6.9 \%$ & $1.7 \%$ \\
Using Turnitin took too much time. & $5.2 \%$ & $40.5 \%$ & $44.8 \%$ & $7.8 \%$ & $1.7 \%$ \\
\hline
\end{tabular}




\section{Training and assistance}

Of all students who used Turnitin, $63.8 \%$ had discussed their Turnitin report with an instructor, writing centre staff, or a friend, and $65.5 \%$ had received in or out-of-class training on how to use it (Table 4). The results suggest that students found the discussions and training useful but not overwhelmingly so.

Table 4: Training and assistance

\begin{tabular}{|c|c|c|c|c|c|}
\hline Survey question & $\begin{array}{l}\text { Strongly } \\
\text { agree }\end{array}$ & Agree & Disagree & $\begin{array}{l}\text { Strongly } \\
\text { disagree }\end{array}$ & $\begin{array}{l}\text { No } \\
\text { response }\end{array}$ \\
\hline $\begin{array}{l}\text { Discussing my Turnitin report with someone (my } \\
\text { instructor, writing centre staff, or a friend) helped } \\
\text { me to understand my problems. }\end{array}$ & $22.7 \%$ & $68.1 \%$ & $7.9 \%$ & $1.1 \%$ & $0 \%$ \\
\hline $\begin{array}{l}\text { The in-class or out-of-class training helped me to } \\
\text { understand how to use Turnitin. }\end{array}$ & $30.9 \%$ & $58.3 \%$ & $10.7 \%$ & $0 \%$ & $0 \%$ \\
\hline
\end{tabular}

\section{Open-ended questions}

Students were asked three open-ended questions. Of the 116 participants who completed the second part of the survey, 60 students responded to the question, "What is the best thing about using Turnitin?" Of these, 44 students, or $73.3 \%$, claimed that it helped them become more aware of plagiarising and helped them avoid it, for example:

The best thing in using Turnitin is that to know exactly how I am capable to paraphrase, summarize, understanding what I am reading and be able to give the same meaning without plagiarism. (Participant 27)

Several also said that it helped to improve their paraphrasing and citation skills: "It allowed me to understand paraphrasing better" (Participant 87 ) and "[Turnitin] helps pick out parts we would have otherwise missed citing" (Participant 25). However, this question elicited one negative response from a student, who suggested that it may be useful for students with weaker academic skills but less useful for others: "Turnitin is useful for students who cannot paraphrase the book or net reading. For those who write after understanding the subject material, it is of little use" (Participant 112).

In addition to determining sections of a paper that may be plagiarized or poorly paraphrased, Turnitin also has a grammar and mechanics feature, which shows students their errors. Although the focus of this survey was on how Turnitin helped students with their paraphrasing and citation skills, several commented on how this feature improved their writing.

In response to the question, "What is the worst thing about using Turnitin?" 48 students responded, with the most common responses related to technical features of Turnitin. In particular, students noted that generating a report was too time-consuming and that there were several log-in issues. Several students commented that they wish they were able to use the grammar feature independently. At the time of the survey, it was not a function of Turnitin that students could use this tool independently. Instead, they had to contact someone in the university writing centre who had to preview the students' papers before students could view the grammar and spelling comments.

Other students commented negatively on false matches, which were not in fact instances of plagiarism. One student noted:

One time I gave a title according to my idea which I felt suitable for the content. It was not taken from the internet, but Turnitin showed me this title is used by another student. This I didn't appreciate. (Participant 8)

Another student wrote a brief comment that implied that one needs to analyze the report rather than simply assuming all matches are plagiarism: "Do not depend turnitin blindly" (Participant 13). Only two students stated that they found Turnitin difficult to use, confusing, or difficult to revise, although 
the comment suggests that the issue is with the student's own ability to revise rather than the software itself: "It will make it difficult to fix everything you have to change" (Participant 33).

A total of 31 students responded to the final open-ended question: "How could UCQ improve the way we use Turnitin?" Students primarily reiterated that they should be able to access the grammar feature independently. Some suggested that Turnitin should be mandatory for all classes and that training and assistance should be available to all students.

\section{Conclusions}

Supporting several previous studies (Betts et al., 2012; Bikowski, 2012; Ledwith \& Risque, 2008; Savage, 2004), the researchers found that students' impressions were very favourable towards Turnitin. Students appeared to appreciate having the opportunity to use Turnitin as a learning tool to help familiarize themselves to academic writing. In particular, they overwhelmingly found that it helped them avoid plagiarism, paraphrase better, and understand problems with citations as it appeared to raise their awareness of these issues. To a lesser degree, students found that Turnitin improved their language skills. Although the researchers cannot determine how they think that their skills improved, in the open-ended questions, a few students commented that seeing the matching sections on the Turnitin report encouraged them to rewrite more times than they would have. In follow-up research, it would be useful to clarify whether students believed these multiple revisions improved their writing. While this research did not specifically address the grammar feature on Turnitin, text responses noted that they found that Turnitin improved their grammar, specifically. Although none of the survey questions asked about the grammar feature on Turnitin, in the openended questions, several students noted the value of the feature.

One of the problems identified in these research findings was that using Turnitin took too much time. Based on the open-ended question results, it seems that students were referring to a 24-hour delay for resubmissions of an assignment. Of the students surveyed, $36.2 \%$ found the reports confusing and had difficulties fixing their writing based on the reports, which is consistent with the findings of Betts et al. (2012), who stated that students need assistance with interpreting their reports. Some also reported frustration with false matches, which is consistent with Nova and Utami (2018). These findings suggest the need for ongoing support for the students both in terms of how to use the software as well as how to interpret the results and revise accordingly. Of the students who received training, a vast majority agreed that it was useful. However, not all students received training. According to the survey results, not all instructors invited a writing centre staff to their classroom and not all students had been aware that assistance or workshops were available. Additionally, students who discussed their reports with someone agreed that it helped them to understand their problems. However, not all students may have availed themselves of the opportunity or have had the time for or access to support. Students who had used Turnitin in their EAP courses were less likely to agree that the reports were confusing, which suggests that the additional time they spent using the tool or perhaps the extra assistance they received using it within the EAP course may have facilitated the learning process.

\section{Pedagogical implications}

Of all participants, a full $89.2 \%$ agree or strongly agree that they worry about accidental plagiarism. This was particularly evident in the students who are less proficient in English, which is not surprising given the linguistic complexities of academic writing. As an educator, this is concerning. If such a high percentage of students experience anxiety over unintentional plagiarism, it seems that we should use resources to help them understand it. That may include providing students access to a plagiarismdetection tool such as Turnitin, which can both reduce students' concerns and, potentially, improve their writing. Both students and faculty need to understand how to use the tool effectively. Workshops, both in and out of class, could usefully be offered regularly throughout the semester. 
These workshops could include how to use Turnitin itself as well as workshops on paraphrasing and citation practices. In fact, this research suggests that best practices for source integration, citations, and referencing should be incorporated throughout the curriculum. Students also need easy access to experts who can help them individually, both with their writing and with the technology. Use of Turnitin, however, would ideally not be used in isolation but be most effectively integrated into a comprehensive plagiarism education program. The conclusions of this research, supporting previous international research, suggests that incorporating such an educational initiative is likely to assist students in gaining a more holistic understanding of plagiarism and academic expectations.

\section{Limitations and future research}

A limitation to this study is that it focused solely on students' perceptions. Although students believed that their paraphrasing and writing skills improved, our study lacks quantifiable evidence. In their study, Biggam and McCann (2010) noted that similarity scores decreased but suggested that it may have been because students had learned how to "get around" the program. While it is indeed important that students believe that plagiarism detection software helps them with their writing, we cannot be certain if their belief is because it truly helped them to become more aware of plagiarism or simply because it helped them to avoid it. Furthermore, many students did not offer comments to the open-ended questions and of those that did, some answers were very brief. To gain a deeper understanding of students' perceptions, it would be useful to conduct focus groups in a future study.

\section{Conclusion}

Academic writing is a daunting task for all, but in particular for second language learners. It has been noted that plagiarism may be a 'necessary phase' that writers pass through as they become familiar with academic writing. As educators, we must help these students through that phase and help them to adapt the conventions of academic writing. This research concludes that plagiarism detection software is likely to have the potential to help students overcome that learning phase as it increases awareness of unintentional plagiarism and encourages students to think more about choices in their academic writing. Not until students become more aware of these issues will they be able to overcome their obstacles and acculturate into academia.

\section{References}

Abasi, A. R., \& Graves, B. (2008). Academic literacy and plagiarism: Conversations with international graduate students and disciplinary professors. Journal of English for Academic Purposes, 7(4), 221233. doi:10.1016/j.jeap.2008.10.01

Bailey, C., \& Challen, R. (2015) Student perceptions of the value of Turnitin text-matching software as a learning tool. Practitioner Research in Higher Education Journal, 9(1), 38-51. Retrieved from http://insight.cumbria.ac.uk/id/eprint/3863/1/Bailey_StudentPerceptions.pdf

Betts, L. R., Bostock, S. J., Elder, T. J., \& Trueman, M. (2012). Encouraging good writing practice in first-year Psychology students: An intervention using Turnitin. Psychology Teaching Review, 18(2), 74-81. Retrieved from http://www.bps.org.uk/ptr

Biggam, J., \& McCann, M. (2010). A study of Turnitin as an educational tool in student dissertations. Interactive Technology and Smart Education, 7(1), 44-54. doi: 10.1108/17415651011031644

Bikowski, D. (2012). Exploring non-native English speaking students' use of technology to improve their paraphrasing skills and avoid plagiarism. In G. Kessler, A. Oskoz, \& I. Elola (Eds.), Technology across Writing Contexts and Tasks. CALICO Monograph. Retrieved from https://calico.org/publications/book-series/technology-across-writing-contexts-and-tasks/ 
Carlozzi, M. (2018). They found it - now do they bother? An analysis of first-year synthesis. College \& Research Libraries, 79(5), 659-670. doi:10.5860/crl.79.5.659

Chandrasoma, R., Thompson, C., \& Pennycook, A. (2004). Beyond plagiarism: Transgressive and nontransgressive intertextuality. Journal of Language, Identity, and Education, 3(3), 171-193. doi: 10.1207/s15327701jlie0303_1

Currie, P. (1998). Staying out of trouble: Apparent plagiarism and academic survival. Journal of Second Language Writing, 7(1), 1-18. doi:10.1016/S1060-3743(98)90003-0

Dahl, S. (2007). Turnitin(R): The student perspective on using plagiarism detection software. Active Learning in Higher Education, 8(2), 173-191. doi:10.1177/1469787407074110

Elander, J., Pittam, G., Lusher, J., Fox, P., \& Payne, N. (2010). Evaluation of an intervention to help students avoid unintentional plagiarism by improving their authorial identity. Assessment \& Evaluation in Higher Education, 35(2), 157-171. doi:10.1080/02602930802687745

Flowerdew, J., \& Li, Y.-Y. (2007). Language re-use among Chinese apprentice scientists writing for publication. Applied Linguistics, 28(3), 440-465. doi: 10.1093/applin/amm031

Gullifer, J., \& Tyson, G. (2010). Exploring university students' perceptions of plagiarism: a focus group study. Studies in Higher Education, 35(4), 463-481. doi:10.1080/03075070903096508

Howard, R. M. (1992). A plagiarism pentimento. Journal of Teaching Writing, 11(2), 233-46. Retrieved from http://journals.iupui.edu/index.php/teachingwriting/index

Howard, R. M. (1995). Plagiarisms, authorships, and the academic death penalty. College English, 57, 788-806. doi: $10.2307 / 378403$

Hyland, F. (2001). Dealing with plagiarism when giving feedback. ELT Journal, 5, 375-381. doi: 10.1093/elt/55.4.375

Johns, A., \& Mayes, P. (1990). An analysis of summary protocols of university ESL students. Applied Linguistics, 11, 253-271. doi: 10.1093/applin/11.3.253

Keck, C. (2006). The use of paraphrase in summary writing: A comparison of L1 and L2 writers. Journal of Second Language Writing, 15(4), 261-278. doi:10.1016/j.jslw.2006.09.006

Ledwith, A., \& Rísquez, A. (2008). Using anti-plagiarism software to promote academic honesty in the context of peer reviewed assignments. Studies in Higher Education, 33(4), 371-384. doi:10.1080/03075070802211562

MacMillan, M., \& Rosenblatt, S. (2015). They can find it but they don't know what to do with it: Adding academic reading strategies to your IL toolkit (ACRL). Retrieved from http://www.ala.org/acrl/sites/ala.org.acrl/files/content/conferences/confsandpreconfs/2015/MacM illan_Rosenblatt.pdf

Nova, M., \& Utami, W. H. (2018). EFL students' perception of Turnitin for detecting plagiarism on academic writing. International Journal of Education, 10(2), 141-148. doi: http://dx.doi.org

Pecorari, D. (2003). Good and original: Plagiarism and patchwriting in academic second-language writing. Journal of Second Language Writing, 12(4), 317-345. doi:10.1016/j.jslw.2003.08.004

Pennycook, A. (1996). Borrowing Others' Words: Text, Ownership, Memory, and Plagiarism. TESOL Quarterly, 30(2), 201-230. doi: 10.2307/3588141

Rolfe, V. (2011). Can Turnitin be used to provide instant formative feedback? British Journal of Educational Technology, 42(4), 701-710. doi: 10.1111/j.1467-8535.2010.01091.x 
Rosenblatt, S. (2010). They can find it but they don't know what to do with it: Describing the use of scholarly literature by undergraduate students. Journal of Information Literacy, 4(2), 50-61. doi: 10.11645/4.2.1486

Savage, S. (2004). Staff and student responses to a trial of Turnitin plagiarism detection software. Proceedings of the Australian Universities Quality Forum 2004, 2-7. Retrieved from http://citeseerx.ist.psu.edu/viewdoc/download?doi=10.1.1.187.5717\&rep=rep1\&type=pdf

Shi, L. (2004). Textual Borrowing in Second-Language Writing. Written Communication, 21(2), 171200. doi:10.1177/0741088303262846

Shi, L. (2012). Rewriting and paraphrasing source texts in second language writing. Journal of Second Language Writing, 21(2), 134-148. doi:10.1016/j.jslw.2012.03.003

Stapleton, P. (2012). Gauging the effectiveness of anti-plagiarism software: An empirical study of second language graduate writers. Journal of English for Academic Purposes, 11(2), 125-133. doi:10.1016/j.jeap.2011.10.003

Thompsett, A., \& Ahluwalia, J. (2010). Students turned off by Turnitin? Perception of plagiarism and collusion by undergraduate bioscience students. Bioscience Education, 16. doi: 10.3108/beej.16.3

Turnitin. (n.d.) Retrieved from https://www.turnitin.com

Walker, J. (2010). Measuring plagiarism: Researching what students do, not what they say they do. Studies in Higher Education, 35(1), 41-59. doi:10.1080/03075070902912994 


\section{Appendix}

\section{Turnitin Survey Questions}

1. I am a student.
A. BNRT
B. PDBN

2. I am in Year
A. 1
B. 2
C. 3
D. 4

3. I used to be a student in English for Academic Purposes (EAP).
A. Yes
B. No

4. I used Turnitin in EAP.
A. Yes
B. No

5. My first language is (Circle one.)
A. Arabic
B. Farsi
C. Urdu
D. English
E. Other. Please name:

6. Plagiarism is a problem at UCQ.
A. strongly agree
B. agree
C. disagree
D. strongly disagree

7. Instructors are too strict about plagiarism.
A. strongly agree
B. agree
C. disagree
D. strongly disagree

8. I worry about accidental plagiarism in my writing.
A. strongly agree
B. agree
C. disagree
D. strongly disagree

9. Have you used Turnitin for your writing?
A. Yes
B. No

If no, why not?

If you have no experience with Turnitin, you are finished with the survey. If you have experience with Turnitin, please continue with the questions below.

10. How many times have you used Turnitin since January?
A. 1 time
B. 2-3 times
C. 4 or more times

11. I was required to use Turnitin for my class.
A. Yes
B. No

12. I use Turnitin for my assignments, even if my instructor doesn't require it.
A. Yes
B. No

13. I understand the benefits of using Turnitin.
A. strongly agree
B. agree
C. disagree
D. strongly disagree

14. Using Turnitin made me more aware of plagiarism.
A. strongly agree
B. agree
C. disagree
D. strongly disagree

15. Using Turnitin helped me to avoid plagiarism.
A. strongly agree
B. agree
C. disagree
D. strongly disagree 
16. I paraphrased better because of Turnitin.
A. strongly agree
B. agree
C. disagree
D. strongly disagree

17. Using Turnitin helped me understand problems with citations.
A. strongly agree
B. agree
C. disagree
D. strongly disagree

18. It is difficult to fix my writing based on the Turnitin report.
A. strongly agree
B. agree
C. disagree
D. strongly disagree

19. Using Turnitin had no effect on my writing.
A. strongly agree
B. agree
C. disagree
D. strongly disagree

20. My language skills improved because of Turnitin.
A. strongly agree
B. agree
C. disagree
D. strongly disagree

21. Turnitin was easy to use and understand.
A. strongly agree
B. agree
C. disagree
D. strongly disagree

22. Turnitin reports are confusing
A. strongly agree
B. agree
C. disagree
D. strongly disagree

23. Using Turnitin took too much time.
A. strongly agree
B. agree
C. disagree
D. strongly disagree

24. I discussed my Turnitin report with someone (my instructor, Writing Centre staff, or a friend).
A. Yes
B. No

25. If yes, discussing the report helped me to understand my problems.
A. strongly agree
B. agree
C. disagree
D. strongly disagree

26. I attended an in-class or out-of-class training session on Turnitin
A. Yes
B. No

27. If yes, the in-class or out-of-class training helped me to understand how to use Turnitin.
A. strongly agree
B. agree
C. disagree
D. strongly disagree

28. What is the best thing about using Turnitin?

29. What is the worst thing about using Turnitin?

30. How could UCQ improve the way we use Turnitin? 